International Journal of Linguistics, Literature and Translation (IJLLT)

ISSN: 2617-0299 (Online); ISSN: 2708-0099 (Print)

DOI: $10.32996 / \mathrm{ijllt}$

Journal Homepage: www.al-kindipublisher.com/index.php/ijllt

IJLLT

\title{
Pidgin Language at Present: The Alternative Language for Nigerian Contemporary Performing Artists
}

OHWONOHWO Titus Rukaye ${ }^{1 *}$ and CHIEDU Rosemary Ebele ${ }^{2}$

${ }^{12}$ Department of Languages, School of General Studies, Delta State Polytechnic, Ogwashi-Uku, Nigeria

Corresponding Author: OHWONOHWO Titus Rukaye, E-mail: ohwonohwotitus555@gmail.com

\section{ARTICLE INFORMATION}

Received: December 18, 2020

Accepted: February 04, 2021

Volume: 4

Issue: 2

DOI: 10.32996/jillt.2021.4.2.8

\section{KEYWORDS}

Pidgin Language, Alternative Language, Nigerian Contemporary

Performing Artists, Nigeria

\section{ABSTRACT}

Pidgin language (PL) is cardinal o many Nigerians especially in the South-South region, where the language is mostly used. The pidgin language is mostly employed to solve the issues of language difficulties in terms of usage. This is because of the enormous population of illiterates in Nigeria. The pidgin language is for everybody: the educated, uneducated, rich, poor, etc. The way it is used in Nigeria and elsewhere does not require one going to school to study it before one can actually speak it. It is a fast-growing language in Nigeria. New lexical items are brought into the province of the language daily especially by Nigerian musicians from the Niger-Delta and Lagos areas. The pidgin language that has been frowned at decades ago is now a contemporary communicative instrument used by different people and for different purposes. This paper, therefore, seeks to demonstrate that pidgin language plays a prevailing role than English Language in Nigeria these days. The paper goes further to state that in the absence of the pidgin language, disseminating messages through songs will not get to the actual target.

\section{Introduction}

Pidgin Language (PL) is salient to many Nigerians especially in the South-South region and most especially in the Niger-Delta area such as Ughelli, Warri, Sapele, Port-Harcourt and Asaba. The pidgin language currently is effectively employed to substitute for the official language (English Language) in Nigeria. This is because of the high degree illiteracy. It is a language for all irrespective of one's profession or discipline. Man especially the illiterate will always look for a convenient means or medium to convey his message. No wonder a popular musician, Helene Isibor once said, "It's the language the average Nigerian understands". (www.designindaba.com) Man's ability to communicate using a language without rules of usage will actually suit his purpose of such communication. This is exactly what most performing artistes are doing. The purpose of a performing artiste communicating via his songs is primarily to convey his preoccupations. This is in line with the words of Ohoneme, M. H. and Okwilague, A. O:

Man, by nature is gregarious because of his ability to communicate. Communication, in turn, facilitates the need for corporation and continuity of the human race in terms of sharing ideas, information, feelings, good governance, socialization and for the purpose of trade and education. The essence of man's communication is principally to convey meaning (Ohoneme \& Okwilague, 2009, para.1)

The pidgin language, which until lately, has been frowned at, both in its oral and written forms, has become a contemporary tool of communication used for so many purposes especially entertainment. This corroborates what Micheal O. Olatunji posits:

Pidgin has been with us since the colonial era. Pidgin has always been regarded as the unofficial language of the "uneducated". The pluralistic nature of Nigeria, consisting as it does of hundreds of ethnics groups with different languages has aided the development of Pidgin English as a popular language in Nigeria. Many popular musicians have used it in their composition and performances to be able to reach a wide audience. (Olatunji, 2001, para. 6)

K C AL-KINDI CENTER $\mathbf{R}$ D FOR RESEARCH AND $\mathbf{R}$ DEVELOPMENT Your gateway to world-class research

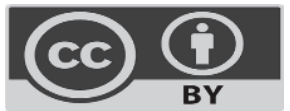

Published by Al-Kindi Center for Research and Development. Copyright (c) the author(s). This open access article is distributed under a Creative Commons Attribution (CC-BY) 4.0 license 
A language form once held as basterdized and for that reason unacceptable, disapproved and shunned in so many spheres of society, would appear to have eventually shed its dark cloak and emerged as people's linguistic "sweetheart" (internet source). This paper, therefore examines song of one selected Nigerian performing artiste, African China, with close reference to his track: "Mr. President" where the pidgin plays a prevailing role. The performing artiste passes ample messages with his revolutionary type of pidginized music.

\section{Pidgin Language in the Musical Industry}

Presently, in Nigeria, the usage of the pidgin language has become extensive. It is now often used in musical industry. This extensive usage is similar to what Munzali Jibril points out. He says:

Nigeria Pidgin (NP), which until recently, has been restricted to oral communication and to the humor column of one newspaper, is now being used for news broadcasts in government owned radio stations and for serious poetry and drama by several well educated poets and playwrights. (Munzali, 1995, para. 1)

Pidgin, as the language refers is usually a combination of languages in contact. It is not the mother tongue of any of its users. It is a language which everybody speaks in Nigeria irrespective of his or her educational background. The above is in line with what T. O. Gana-Ikilama says regarding those speaking pidgin. He demonstrates that, "pidgin is a language, not only in the primary schools, but also in the secondary schools and higher institutions. Again, this happens because students are drawn from diverse linguistic backgrounds." (Gana - Ikilama, 1990, para. 7)

The English Language alone could not have increase the demand of the products (songs/music) of Nigeria performing artistes. The pidgin language is valuable to the lives of good number of Nigerians and to pull it from musical entertainment could be of serious consequences to the musical industry. In addition to the above, the entertainment coming from performing artistes is a medium employed to report the ills of the government. They, the artistes, have fought the Maladministration of those in power (government). Their preaching via their songs (music) had informed he masses that government is not living up to expectation. All these pieces of information are disseminated through the pidgin language in Nigeria. To the performing artistes in Nigeria, the pidgin language is a veritable instrument and the only vehicle free of hurdles in their possession to convey their multiple themes to the general public or target audience. Gani-Ikilima opines that "pidgins are central to the lives of some millions of people all over the world and to dismiss them because of prejudice can be of serious consequences." (Gana- Ikilima, 1990, para. 4) The Nigerian people are drawn from different linguistic backgrounds. Faced with this situation, the musical industry has no other option than to glue to the use of pidgin language as an easy medium of communication.

In Nigeria today, the contemporary musicians need good medium through which they can transmit their music and such medium is the pidgin language. The pidgin language is a Lingua Franca that helps to unify people in Nigeria. "The Pidgin Language has powerful and growing cultural influence across all classes" (www.thejakartpost.com/2019).

From the aforementioned, the pidgin is a messenger to the Nigerian performing artistes. They send their songs through the pidgin language to their recipients (listening audience). According to Ben Elugbe, "Nigeria pidgin is like a child who has no father but everybody sends him on errands". (Elugbe, 1995, para. 1)

From earliest history, man has recognized the power of music to express feelings, stir emotions and influence thoughts and actions. By means of music, primitive man communicated with others. He found delight in work and exercise, he expressed his love and fear, he grew in bodily strength, grace and with music, he went to fight battles (www.takprokectresources.cm/ang15php).

The Nigerian performing artistes involve in the usage of pidgin language extensively believing is the only available tool of communicating to their listening audience. It is also a conduit through which their everyday experiences especially social ills in their society could be transmitted to the general public. This belief of the Nigerian musicians is not far-fetched from what Chinua Achebe said as cited by Mabel Osekwe, regarding the English Language as a means for him to express his African experience, captures this explicitly when he summits that:

I feel that the English Language will be able to carry the weight of my African experience. But it will have to be new English, still in full communion with its ancestral home but altered to suit its new African surrounding (Osakwe, 2012, para. 10)

A vendor will always seek a better strategy through which he can market products. The best strategy left for the Nigerian performing artiste is the pidgin language. This language is the vehicle that will transport the products (music/songs) faster to the listening audience or public. The language in question will make it easy for comprehension by anyone. This view correlates the 
words of Emman Osakwe. He points out that, "it is through language that people transmit information, ideas, attitudes and emotions to one another." (Osakwe, 2012, para. 9)

In the above sense, we can boldly say that the communication of Nigeria performing artistes, especially African China, is built around the pidgin language for the purpose of sharing meaning and creating awareness. The language is the veritable tool employed by African China for pouring out his preoccupations especially the weaknesses of our leaders.

\section{Condensed Biography of African China}

African China (real name: Chinagorom T. Onuoha) was born $7^{\text {th }}$ August, 1978 in Orile, a ghetto side of Lagos, Nigeria. His educational backgrounds were at Metropolitan Primary School and Iganmu High School. The ghetto-born reggae musician is from Imo state and is the last child of his mother.

African China as he is popularly known is one of Nigeria newest young and top rated artistes. He started his music career in 1985 at the tender age of seven (7). He fully went into music at the age of eighteen (18) in the year 1996, after completing secondary school. He could be described as a Nigerian reggae artiste. African China describes his music as a type of music that is basically African in nature, while labeling it as "Pidgin Reggae" style. He became a professional in 1999.

African China received his first award at the Nigerian International Song Festival before releasing his debut album: "Crisis" that later went on to win many awards: Best Reggae/dance hall at the Fanta Fame Musical Award, 2003 Merit Award, Unification Peace Award from the OPC, $1^{\text {st }}$ Nigerian Entertain Award, Grand Hotel Award for best performance and many more.

He went onto release his sophomore album titled "Mr. President", one of the hottest selling album in Nigeria. (http://nuwater.blogspot.com/2008/07/interviwe-with-african-china.html).

\section{Pidgin Language in the Music of African China: "Mr. President"}

\section{Verse 1}

Food e no dey

Brother eh water no dey

And our country no good o

Everyday for thief

One day for owner e

Poor man wey thief maggi

Omo, dem go show im face

For Crime Fighter

Rich men wey thief money

Omo, we no dey see their face

For Crime Fighter

Tell me something now rude boy

Rich man go dey halla prayer...

Poor man go dey shout...

Rich man go dey halla prayer...

Poor man go dey shout...

Make una lead us well

No let this nation to fall inside well

- Chorus

Mr. President (lead us well)

If you be governor (govern us well)

If you be senator (senate us well)

If you be police (police well well no dey take bribe)

Performing artistes are bound to express their preoccupations via their music/song. The music/songs which are the products bearing the feelings and experiences of the performing artistes, are usually conveyed to the listening audience by a vehicle known as pidgin language. This vehicle is the type that will get to the recipients on time. On time here means easy comprehension by everybody out there. 
The above music/song by African China is a portrayal of his sad experiences in Nigeria. He employs his music to point out certain weaknesses he discovers in Nigeria leaders and security personnel.

The music opens with complaints on shortage of food and water: 'food e no dat/brother eh water no dey' (lines 1-2). These are the basic necessities in life for man that should be there at all times, but they are not there. The shortage or absence of these amenities provokes African China. And the only means available to transmit this message to the door steps of the masses is through the pidgin language.

The performing poet goes further to explore the social ills in the Nigeria society. This time he points out that his country is completely bad. He cries out by referring to the leaders in Nigeria as thieves and the masses as the owners: 'And our country no good o'/'everyday for thief'/'one day for owner e' (lines 2-5). Again, the only tool employed by the musician to make his compliant known to the general public is the pidgin language.

The Orile-born performing artiste did not leave any stone unturned regarding his fight against social ills in Nigeria. He also makes reference to the common man (the poor in the society) and the rich man. This

time he says: poor man wen thief maggi'//omo dem go show im face'/ 'for Crime Fighter'//rich man wen thief money'/'omo we no dey see im face'/ 'for Crime Fighter'/'tell me something now rude body' (lines 6-12).

Crime fighting to African China is one-sided. To him, double standard should not be part of crime fighting. The performing artiste is saying that each time a poor man steals, no matter how puny or irrelevant the object or commodity is, the culprit is displayed on television screen under a programme known as "Crime Fighter". Crime Fighter is a television programme in one of the stations in Lagos, Nigeria, that reports crime within Lagos. When a rich man or important figure in Nigeria steals, his case is not brought before "Crime Fighter" let alone displaying him on the television screen. This is the double standard condemned by African China through his song: "Mr. President". He is of the opinion that everyman should be treated equally irrespective of status of any kind. He goes further to call himself: 'rude boy' (line 2). The phrase 'rude boy' does not actually makes him rude rather depicts him as bold. The phrase in question has to do with boldness of the mind. African China is one among few who are bold to point out through their music/songs, the social evils eating so deep into the fabrics of the Nigeria society. Again, the pidgin language remains his medium to reach the listening audience. The pidgin language enables African China to encode his experiences and feelings by assigning names to them.

In line 17 of the song under analysis, the performing artiste tells those in charge of administration of Nigeria, to lead the Nigerian masses or the nation well, thus: advising the Nigerian leaders especially 'Mr. President' not to allow the nation collapse, thus: 'no let this nation to fall inside well' (line 18).

From the above so far, it is very obvious that African China is a conscience of the Nigerian society. Again, this is another level at which the Pidgin language establishes its way in the music of African China.

Verse 2

Fuel e no dey
Brother eh transportation no dey
And our road e no good o
What about the NEPA people o
We no get light
Everybody just dey halla
Fuel no dey, na how we wan survive
Many youth ready for work
But as work no dey
Na how dey wan survive
We be giant of Africa
But to get visa enter Ghana
Na WAEC
...

In the second verse of "Mr. President", African China explores additional areas in the Nigerian society where the masses should have benefited. This also merits discussions. In the first line of verse 2 of the song, the performing artiste points out the issue of constant fuel scarcity in Nigeria: 'fuel e no dey' (line 1). He also stretches his pre-occupation to that of high cost of transportation and the dilapidated roads: 'and our road e no good o' (lines 2-3). As earlier mentioned, the performing poet in question did not 
leave any stone unturned. He goes ahead to point out the epileptic electricity supply and complete power failure in some parts of Nigeria: 'what about the NEPA people'/'we no get light' (lines 4-5).

African China is not only a performing poet but also a reporter. He is busy reporting to us the things the Nigeria government should have done but failed to do. In lines 8-13, the performing artiste laments for the jobless youths in Nigeria who do not know how to survive. He goes further to satirize Nigeria as a country that claims to be the giant of African but getting visa to enable someone travel to Ghana is herculean. The song man compares the difficulty of travelling to Ghana with that of obtaining a WASC (West African School Certificate).

All the issues mentioned in the song of African China perturb him seriously hence he has to report this with his music and again with the pidgin language. The songstar has no perfect tool to work with than the pidgin language. It is the only good instruments in his possession which will enable him communicate his message to his target audience (the general public). We think this is the only reason African China decides to inculcate into his song the pidgin language. Music generally integrates people in a particular area. This is the case of Nigeria. Therefore, the use of pidgin language by performing artistes especially the likes of African China has assisted in a long way to integrate Nigerians each time the music: "Mr. President" is on the air, it usually arrests the attention of everybody around there. It captures them because of the items of the social ills mentioned and most especially the language through which the music disseminates. The pidgin has become a veritable language of performing artistes because is the most popular among the numerous languages spoken in Nigeria at present. It is the language of the people. It is a language that spice up communication.

\section{Conclusion}

In as much as we would have loved to continue in this discussion of pidgin language in the music of performing artistes in Nigeria, it will be redundant on our part. We therefore suggest that next time you visit a record store, go for music rendered in Pidgin language.

Pidgin language in music provides us with a broad window through which we see clearly and know the social evils plaguing our society. This is exactly what African China has succeeded in doing for us. Therefore, from the analysis done so far in this paper, we can boldly say that performing artistes would express their experience and feelings better with the help of pidgin language.

\section{References}

[1] Elugbe, B. (1995). Nigeria pidgin: problems and prospects. In A. Bamgbose, A. Banjo \& A. Thomas (Ed.), New english: A west african perspective (pp. 284). Ibadan intec printers Itd.

[2] Gani-Ikilama, T.O. (1990). Use of nigerian pidgin in education? Why not?In E.N. Emenajo (Ed.), Multilingualism minority language and language_policy in Nigeria_(pp.221). Agbor central books Itd.

[3] Jubril, M. (1995). The elaboration of the functions of nigerian pidgin. In A. Bamgbose, A. Banjo \& A. Thomas (Ed.), New Englishes: A west African perspective (pp.232). Ibadan Intec Printers limited.

[4] Ohoneme, M.H. \& Okwilague, A.O. (2009). A lexical-semantic analysis of selected bill board advertisement in Ibadan metropolis. NATECEP Journal of English and communication studies, 5(3), 2.

[5] Olatunji, M. O. (2001). The use of Pidgin English in contemporary Nigerian music: A new approach towards national identity. Humanities Review Journal, 1(1), 41-46.

[6] Osakwe, E. (2012). The making of social man for society through language. In M. Osakwe (Ed.), Language communication and human capital development in a globalized world (pp. 71). Ibadan kraft books Ltd.

[7] Osakwe, M. (2012). Tending, bending and breaking vagabond english for global needs. Delsu Abraka Nigeria. 


\section{Appendix}

“MR. PRESIDENT"

\section{- Verse 1}

Food e no dey

Brother eh water no dey

And our country no good o

Everyday for thief

One day for owner e

Poor man wey thief maggi

Omo, dem go show im face

For Crime Fighter

Rich man wey thief money

Omo, we no dey see their face

For Crime Fighter

Tell me something now rude boy

Rich man go dey halla prayer...

Poor man go dey shout...

Rich man go dey halla prayer...

Poor man go dey shout...

Make una lead us well

No let this nation to fall inside well

\section{- Chorus:}

Mr. President (lead us well)

If you be governor (govern us well)

If you be senator (senate us well)

If you be police (police well well no dey take bribe)

\section{- $\quad$ Verse 2}

Fuel e no dey

Brother eh transportation no dey

And our road e no good o

What about the NEPA people $o$

We no get light

Everybody just dey halla

Fuel no dey, na how we wan survive

Many youth ready for work

But as work no dey

Na how dey wan survive

We be giant of Africa

But to get visa enter Ghana

Na WAEC

... (Internet Source) 